\title{
A Lingua Franca in the post-Brexit EU*
}

\section{Una lengua franca en la UE post-Brexit}

\author{
Victor Ginsburgh \\ ECARES, Université Libre de Bruxelles \\ CORE, Université Catholique de Louvain
}

\author{
Juan D. Moreno-Ternero \\ Universidad Pablo de Olavide
}

\begin{abstract}
Confidence in the institutions of the EU was obviously shocked by the intention of Great Britain to Brexit. We suggest introducing a lingua franca in the EU which could partly repair this irritation, as surveys show that citizens would be very favourable to such an idea. We also advocate that the EU should help member countries by contributing to the cost of such an endeavour. Each country would have the right to claim a compensation based on the number of young citizens who do not (yet) speak the chosen common language. The EU budget would then be distributed fairly, in proportion to the claims. We assume that the choice should be made among three languages: English (yes, even if Brexit takes place), German and French, and analyse the pros and cons of each of them. We finally look at what the existing voting procedures used by EU bodies would lead to. The result of such a vote is far from being obvious, and maybe the vote should be left to countries, with the exception of those whose native languages are English, German and French.

Keywords: European Union, lingua franca, resource allocation, sacrifices, Brexit.
\end{abstract}

JEL classification: D63, D72, Z13.

\section{Resumen}

La confianza en las instituciones de la UE se ha visto obviamente mermada tras la decisión de Gran Bretaña de poner en marcha el Brexit. Para paliar parcialmente esta irritación, sugerimos la implantación de una lengua franca en la UE, una idea muy popular entre los ciudadanos según muestran las encuestas. Sugerimos también que la UE debería ayudar a los países miembros contribuyendo a cubrir el coste de dicha iniciativa. Cada país tendría el derecho de reclamar una compensación basada en el número de sus jóvenes que no hablan (aún) la lengua común elegida. El presupuesto destinado por la UE debería repartirse de forma justa, en proporción a dichas reclamaciones. Suponemos que la elección debería restringirse a tres idiomas: inglés (sí, incluso si el Brexit finalmente ocurre), alemán y francés, y analizamos los pros y contras de cada opción. Finalmente, exploramos los resultados que obtendríamos con los procedimientos de votación existentes en las instituciones de la UE. El resultado de dicha votación dista de ser obvio y quizás el voto debería ceñirse a los países cuyos idiomas nativos no sean el inglés, alemán o francés.

Palabras clave: Unión Europea, lengua franca, asignación de recursos, sacrificios, Brexit.

Clasificación JEL: D63, D72, Z13.

* The first author is grateful for comments by Mathias Dewatripont, Michel van den Abeele, Philippe Van Parijs, Anne Weyemberg, and to the many participants at a conference organized by Université Libre de Bruxelles on November 26, 2019, on the topic 'Quelle lingua franca pour 1'UE après le Brexit'. The second author acknowledges financial support from the Spanish Ministry of Economy and Competitiveness (ECO2017-83069-P). 


\section{Introduction}

The tragic first half of the 20th century in Europe was followed by an unprecedented peaceful and prosperous period in the continent, that many among us associate with the development of the concept of a European Union (EU). ${ }^{1}$ The EU is however facing a crucial moment of its history. The pro-Brexit referendum in June 2016, as well as the emergence of populist movements in an increasing number of countries, make many Europeans wonder whether the concept born after WW2 is still sustainable. Europe is obviously in need of new measures that would (or could) revive Schuman's Declaration and Jean Monnet's Plan, which both triggered the creation of the Common Market in 1956, and eventually led to the EU.

The implementation of a common language (in addition to each citizen's mother tongue) would certainly be a natural way to increase the cohesiveness and the solidarity between European citizens and reinforce the effects of the Erasmus program which enthuses young students. This is explicitly illustrated by the following results of a Special Eurobarometer survey on languages taken in 2012.2

(a) $84 \%$ of EU citizens totally agree or tend to agree ${ }^{3}$ that learning at least a second language is useful,

(b) $69 \%$ totally agree or tend to agree that they should be able to speak a common language, though, $27 \%$ disagree; agreement is nevertheless larger than $60 \%$ in 20 EU countries, ${ }^{4}$

(c) $77 \%$ totally agree or tend to agree that language skills should be a policy priority,

(d) a reasonably large fraction of the population (29\%) believes that the preferred way to learn a language is free lessons, but learning in another country where the language is spoken is also evoked by $18 \%$,

(e) the most effective way to learn a language is at school (69\%),

(f) four languages are most used in conversations: English (38\%), French (12\%), German (11\%), Spanish (7\%). These are, with Italian and Polish, the native languages of the most populated EU countries, ${ }^{5}$

(g) learning of languages should be free.

\footnotetext{
${ }^{1}$ A notable exception during this period was, obviously, the devastating conflict in the Balkans.

2 Special Eurobarometer 386, Europeans and their Languages, 2012. Note that, at the time, Croatia was not yet a member state. Neither had the Brexit referendum occurred, obviously. We believe, nevertheless, that the results would not be very different today. Note also that the data used in (a)-(g) below are based on the 2012 Special Eurobarometer survey, because they contain more information than those of the 2006 survey. The 2006 Special Eurobarometer survey is used in the other sections, to be in conformity with the Ginsburgh and Moreno-Ternero (2018) paper, on which the present paper is based.

${ }^{3}$ Five answers were possible: 'Totally agree', 'tend to agree', 'tend to disagree', 'totally disagree', and 'do not know.'

${ }^{4}$ The exceptions are Denmark (58\%), Sweden and Bulgaria (57\%), Romania (51\%), Estonia (48\%), Latvia (46\%) and Finland (40\%).

${ }^{5}$ Italian and Polish were either not considered among the choices in the survey or are not cited.
} 
This leads us to believe that the EU should devote an additional budget (bundled or associated with the Erasmus program), that would cover at least part of what it costs to teach a language to young generations. The idea could be implemented in various ways, such as paying part of the education of future teachers of the chosen lingua franca, financing schools to hire language teachers, or providing vouchers to families to enrol their children in extra-school language academies.

Assuming that the EU agrees on the need (and feasibility) of implementing a lingua franca, there are still three important issues, which we try to address in this paper:

1. How should the budget be distributed among the EU's countries?

2. How should the possible linguae francae be chosen?

3. What would be the outcome of a vote on the final choice of the lingua franca?

This paper is a natural follow-up of Ginsburgh and Moreno-Ternero (2018) which explores possible compensation schemes for implementing a lingua franca in the EU, and looks essentially at the distributional issue. Here, the main innovative aspect is to consider 'sacrifice measures' and to deal with items 2 and 3.

The paper is organized as follows. In Section 2, we discuss whether English could remain an official language in the EU after Brexit (which would simplify the choice of the lingua franca). Section 3 introduces the distribution model (item 1). Section 4 provides the results and discusses the choices between English, German and French as lingua franca (item 2). ${ }^{6}$ Section 5 is devoted to the voting problem on the lingua franca (item 3) and Section 6 concludes.

\section{English as an official language after Brexit?}

For the time being, the EU includes three countries in which English is an official language: the United Kingdom, the Republic of Ireland and Malta. The first two became members in 1973, and the third in 2004. The UK obviously chose English as its EU official language. Ireland selected Irish not only because, under its constitution, it is its first official language, but also because it was an easy choice, since English was already represented by the UK. Malta also has two official languages: Maltese, its national language, and English, which is spoken by some $90 \%$ of its citizens. Their choice of the official EU language was therefore also easy, for the same reason as the one made by Ireland, and they chose Maltese.

As each member country can choose one language only, English will no longer be an official language in the EU if the UK eventually 'brexits'. There are, nevertheless,

\footnotetext{
${ }^{6}$ It is often suggested that the lingua franca should be a language that is spoken by few people (say Latvian, Maltese or, even Esperanto, which would finally make happy its inventor, Ludwig Zamenhof) as it would make no "big country" jealous. We exclude this possibility for being economically unfeasible.
} 
three ways to save the current status of English as official (and working) language in the EU: ${ }^{7}$

(a) to argue that it is the language that disenfranchises the smallest number of EU citizens, and that it probably is the most spoken language in the world, with the exception of Chinese and Arabic if one puts all their local dialects in the same basket,

(b) to convince Ireland or Malta to replace their current EU official language (Irish or Maltese) by English, which may of course irritate the feelings of their citizens.

(c) to incite Luxembourg, which in 1958 renounced to its right to have Letzebuergesch as an official language, to choose English after Brexit, though this is unlikely to happen, since Luxembourg's national language (Letzebuergesch) tries to make a comeback and "decided to open negotiations with the EU institutions to find agreement on an administrative arrangement". ${ }^{8}$

In all cases, the European Council will have to meet and cast a vote. This is indeed implied by art. 342 of the Lisbon Treaty which specifies that:

The rules governing the languages of the institutions of the Union shall, without prejudice to the provisions contained in the Statute of the Court of Justice of the European Union, be determined by the Council, acting unanimously by means of regulations.

Notice that changing of rules needs a unanimous vote..$^{9}$ It is fairly unlikely that solution (a) that is, keeping English as an official language in the EU after Brexit, will be accepted by the representatives of large countries such as France, Germany, Italy, Poland or Spain, some of which (especially Germany and France) keep complaining that their own language is overshadowed or dominated (especially as working language) by English. And Brexit makes it even worse since if English disappears as an EU official language, the relative number of speakers of the other important languages increases -whatever the hypothesis that is made on the proficiency with which each language is spoken- and though English will still be spoken by non-English citizens, the relative number of native English speakers in the EU will seriously decrease, since 60 million British citizens will be leaving the Union.

If, alternatively, solution (b) is chosen -that is, either Ireland or Malta accepts to change their EU language to English- it is not clear that the decision of the EU Council will be unanimous. It may well be that Germany and/or France will abstain, or even vote against, for the reasons discussed above, even if they may be seen as counterproductive. In addition to this, Modiano (2017, p. 317-318) suggests that even if Ireland or Malta switched to English, it would be very difficult for them to defend

\footnotetext{
${ }^{7}$ See also Ginsburgh et al. (2017).

${ }^{8}$ EURACTIV.com with AFP. Luxembourgish makes comeback, bid for EU approval. See https://www. euractiv.com/section/languages-culture/news/luxembourgish-makes-comeback-bid-for-eu-approval/

${ }^{9}$ One may also think that repealing the word "unanimously" is a possibility though the vote on this issue should be unanimous as well.
} 
the language as effectively as the British did, and English may even be removed as working language by the Commission and the Parliament. In addition, this solution does not necessarily imply that English could remain a working language (at the Commission and the Parliament), as assumed for example by Mair (2019).

Solution (c) can also raise an eyebrow for the same reasons as solutions (a) and (b) and for the reason discussed earlier, that Letzebuergesch could make a comeback as an EU language.

Notice, however, that a legal interpretation of article 342 (also called Regulation no. 1, since it was written in 1958 at the time the EEC Treaty ${ }^{10}$ was signed) is that English will not be removed, since this would need a unanimous vote. The article

has [indeed] often [been] amended, but only in order to add languages. It now lists 24 languages as being both official and working languages [and] legally speaking, all official languages are also working languages. English could only cease to be an official and working language if Regulation no. 1 were amended (unanimously) and this is not going to happen. As for the effective use of languages in the various institutions, there is no reason why anything would change as a consequence of Brexit (De Witte, 2019).

Alternatively, one could have thought, or found sound that, if the addition of a new language comes with the entry of a new country (English entered in 1973, at the time Great Britain became a member state), it would be logical for a language to exit when a country that carried the language at its entry, exits. Or at least, that the Council would have to vote unanimously to keep the language, which is not the same as unanimity to drop the language.

Anyway, whether in or out, we assume that English could still become a lingua franca, since what is really needed for the EU is a common language, whichever it is, official or not, but spoken by as many European citizens as possible.

\section{Distributing the budget among countries}

We follow Ginsburgh and Moreno-Ternero (2018) and assume that the European Commission would provide a budget to be distributed among countries in order to promote the learning of a lingua franca. We argue that this distribution should be based on the needs (claims) of countries. To determine these needs, we make the following reasonable assumptions:

(a) each country $i$ has its own (unique) official language $l_{i}$ which is also an official language of the EU, ${ }^{11}$

${ }^{10}$ The EEC included six member states (Belgium, France, Italy, Luxembourg, The Netherlands and West Germany), and lived with only four official and working languages (Dutch, French, Italian and German). Luxembourg had waived its native language, and official Belgian languages ( Dutch, French and German) were included thanks to The Netherlands, France and Germany.

${ }^{11}$ There are a few exceptions: Austria shares its German with Germany; Belgium has no official language by itself, but the three languages that are spoken in the country (Flemish, French and German) are also official languages in The Netherlands, France and Germany; the official language in the EU part of Cyprus is Greek; Ireland and Malta have both English as one of the official languages, the other being Gaelic or Maltese respectively; and Luxembourg has no EU official language but most of its citizens speak either German or French, though it may come back in one form or another. 
(b) the smaller the lexicographic distance $d\left(l, l_{i}\right)^{12}$ between the official language $l_{i}$ of the country and the lingua franca $l$, the smaller the cost of learning the latter, ${ }^{13}$

(c) the claim that each country can exercise on the common budget is based only on the number of young individuals (ages 15-26) who do not speak the lingua franca,

(d) the claim by each student of the lingua franca is set to 500 Euros (though this amount can be increased or decreased without changing the main results that follow),

(e) the European Commission would be ready to spend a budget $E$ per year to increase the feeling of unity among Europeans, in the same way as it does with its educational Erasmus program, set at 2.3 billion Euros per year between 2014 and $2020 .{ }^{14}$ Here, we set the total EU subsidy $E$ to one billion Euros. ${ }^{15}$

Based on the above items, the $\operatorname{claim} c_{i}^{l}$ of country $i$, computed as:

$$
c_{i}^{l}=500 d\left(l, l_{i}\right) n_{i}^{l},
$$

is equal to the number of citizens in the 15-26 years old cohort $n_{i}^{l}$ who do not speak lingua franca $l$, weighted by the distance $d(l, l i)$ between the country's official language and lingua franca $l$, multiplied by 500 (Euros), the annual subsidy to help or give an incentive to individuals to learn the common language.$^{16}$ Let $C=\sum_{i=1}^{26} c_{i}^{l}$ be the aggregate claim. It is natural to assume that $E<C$, for otherwise each country could receive what it claims.

This problem is mathematically equivalent to the so-called problem of adjudicating conflicting claims formalized by O'Neill (1982). ${ }^{17}$ For simplification, here we only consider the focal rule from this literature, namely, the so-called proportional rule, for which normative foundations, as well as overwhelming evidence of positive support, abound in the literature (e.g. Thomson, 2003, 2015, 2019). Formally, country $i$ will receive its part $P_{i}^{l}$ from the EU budget, where:

$$
P_{i}^{l}=\frac{E}{c} c_{i}^{l}
$$

Table 1 collects the countries' claims as well as the (proportional) allocations for the resulting claims problems. ${ }^{18}$ Claims and EU subsidies are computed for three

12 In this paper, we use the distances computed by Dyen et al. (1992).

13 To simplify, we assume that immigrants know the language of the country in which they live. Taking account of them would not change the results very much. We also assume that all Irish people know English.

14 See Erasmus+Programme Guide, Version 2 (2017), p. 13.

15 It is easy to change both the claim by student and the total budget.

${ }^{16}$ Alternative definitions of claims could be considered exploring some of the methods formalized by Ginsburgh et al. (2017).

17 The reader is referred to Thomson $(2003,2015,2019)$ for extensive reviews and surveys of the sizable literature dealing with this problem.

${ }_{18}$ For Belgium, we consider a weighted sum of the distances from Flemish and French to the lingua franca (with weights 0.6 and 0.4 , respectively, representing the shares of Flemish and French speaking populations). We ignored the very small German speaking minority since most of them also speak French, and, to simplify, we also assume that all Irish citizens speak English. 


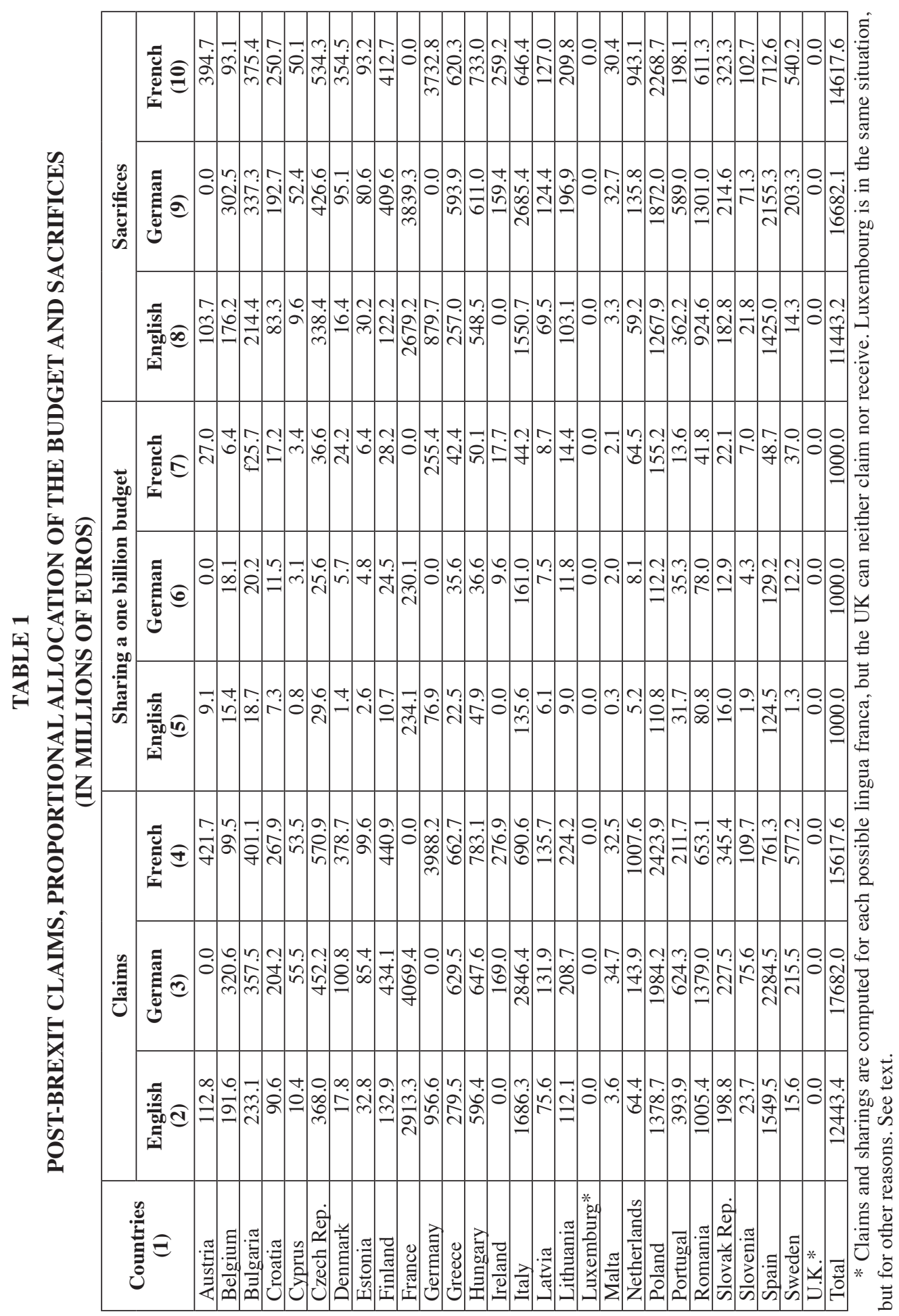


possible linguae francae (English, German and French) and each EU country. They are based on the pre-Brexit situation though, obviously, the UK would not be allowed to claim or get a share if it 'brexits' ${ }^{19}$ Columns (2) to (4) and (5) to (7) contain claims $c_{i}^{l}$ and budget shares $P_{i}^{l}$, respectively. Columns (8) to (10) represent the sacrifice each country $i$ would have to support if language $l$ were selected as lingua franca, that is $c_{i}^{l}-P_{i}^{l}$.

According to Table 1, Austria, for instance, would be entitled to claim 112.8 million, 0 and 421.7 million if English, German or French would be chosen as lingua franca by the EU. It would receive 9.1,0 and 27 million as subsidy from the EU, and would have to sacrifice 103.7, 0 and 394.7 million of Euros to support the teaching of the lingua franca. Clearly, Austria's choices would be German first, English second and French third. Greece, for instance, would choose English first (sacrifice of 257.0), German second (sacrifice of 593.9) and French third (sacrifice of 620.3).

\section{Choosing a lingua franca}

In a pre-Brexit EU, it would, at first glance, be hard to argue against English as the de facto best candidate lingua franca..$^{20}$ It was indeed the best-known language in the EU with $37 \%$ of speakers for whom it is more than a basic language. The same numbers for German, French, Italian, Spanish and Polish are 25, 20, 13, 11 and $8 \%$ respectively. ${ }^{21}$ And there would still be $28 \%$ of EU citizens speaking English after Brexit. The other languages would respectively be spoken by 28, 21, 15, 12 and 9\%. Only German could thus compete with English after Brexit (see Ginsburgh et al., 2017, p. 148). It is spoken by some 30 million more natives than English (implying that English is much more widespread in the EU than German). The last row of Table 1 (Total) shows that English would require the lowest total claim (some 12.4 billion euros), compared to the two other two languages, and therefore also require the lowest total sacrifice.

In what follows, we look at two different scenarios. The first is choosing among the three main languages (English, German and French), ${ }^{22}$ either forgetting the very likely scenario that English would lose its status as official language in the EU, or assuming that it would anyhow be useful as lingua franca, and benefits might be associated to it. The word and in the previous sentence is crucial, since, though EU countries may accept English for reasons of efficiency, they would be less enthused by the idea of subsidizing its learning. One could of course hope that English speaking countries (and definitely the UK) may be happy to pay the one billion Euros

\footnotetext{
${ }^{19}$ Luxembourg is also excluded but because its language, Letzebuergesch, is not an EU official language.

20 See, for instance, Melitz (2016) and some of the arguments presented therein.

21 See Fidrmuc et al. (2007), and Special Eurobarometer 243 (2006).

22 Spanish could be included in the set of choices. In Europe, it is, however, hardly known in other countries than Spain, though, in the world, it is certainly spoken by more people than German. Likewise, Italian is spoken by more EU citizens than Spanish, but again, it is hardly used elsewhere than in Italy.
} 
needed to subsidize other EU countries. After all, the UK makes piles of money with its language as is made clear by Lord Kinnock in his former capacity as chair of the British Council (the United Kingdom's international organization for cultural relations and educational opportunities). In the introduction to Graddol's (2006) report he writes that: "the English language teaching sector directly earns 1.3 billion pounds for the UK as invisible exports and our education related exports earn up to 10 billion pounds a year more." Grin (2005) estimates the amount at some 17 to 18 billion euros, roughly the same amount as Kinnock.

The second scenario is that Brexit finally happens, English loses its status as official and/or working language in the EU, and the European Commission rebuffs English as a possible lingua franca. Then, the choice would be restricted to two languages: German and French.

\subsection{German or French, and why not, English?}

Partly motivated by the arguments raised above, we examine the possibility of choosing between English, German and French as lingua franca in the post-Brexit EU. For clarity, columns (2) to (4) of Table 2 reproduce the sacrifices contained in columns (8) to (10) of Table 1. The following conclusions obtained from Table 2 support the choice of English despite the fact that there will be some 60 million less native speakers within the EU. ${ }^{23}$ The cells of columns (2)-(4) are shaded or not shaded. The dark grey shade is used for the smallest sacrifice; the light grey shade is used for the largest sacrifice, while the non-shaded cells show the 'in between' sacrifice. We notice that:

1. English yields the lowest overall sacrifice, by a wide margin of more than three billion Euros as can be seen from the last row of Table 2,

2. English yields the lowest sacrifice among the three candidate languages for an overwhelming majority of 18 countries (dark shaded cells in column (2)),

3. English never yields the highest sacrifice for any of the 26 countries (ignoring Luxembourg and the UK),

4. As shown in columns (3) and (4), there are eight countries for which the sacrifice would not be the smallest if English were chosen. Four of them (Austria, Belgium, France and Germany) have as official languages French or German. The other four countries (Italy, Portugal, Romania and Spain) would be better off with French, since they would have to learn a language that is closer to theirs.

Though item 2 above shows that a large number of countries would 'gain' in terms of sacrifice, their citizens represents only $29.2 \%$ of the EU population. Item 4

${ }^{23}$ It has been argued, after all, that only $4 \%$ of the conversations in English happening in the world involve only native speakers. See https://lemongrad.com/english-language-statistics. 
TABLE 2

SACRIFICES (IN MILLIONS OF EUROS) AND POPULATION

\begin{tabular}{|c|c|c|c|c|c|c|c|}
\hline \multirow[b]{2}{*}{$\begin{array}{c}\text { Countries } \\
\text { (1) }\end{array}$} & \multicolumn{3}{|c|}{ Sacrifices } & \multicolumn{2}{|c|}{ Winners/Losers } & \multicolumn{2}{|c|}{ Population } \\
\hline & $\begin{array}{c}\text { English } \\
\text { (2) }\end{array}$ & $\begin{array}{l}\text { German } \\
\text { (3) }\end{array}$ & $\begin{array}{c}\text { French } \\
\text { (4) }\end{array}$ & $\begin{array}{c}\text { German } \\
\text { (5) }\end{array}$ & $\begin{array}{c}\text { French } \\
\text { (6) }\end{array}$ & $\begin{array}{l}\text { Millions } \\
\text { (7) }\end{array}$ & $\begin{array}{c}\text { Shares } \\
\text { (8) }\end{array}$ \\
\hline Austria & 103.7 & 0.0 & 394.7 & -103.7 & 291 & 8.77 & 1.98 \\
\hline Belgium & 176.2 & 302.5 & 93.1 & 126.3 & -83.1 & 11.56 & 2.61 \\
\hline Bulgaria & 214.4 & 337.3 & 375.4 & 122.9 & 161 & 6.99 & 1.58 \\
\hline Croatia & 83.3 & 192.7 & 250.7 & 109.4 & 167.4 & 4.14 & 0.93 \\
\hline Cyprus & 9.6 & 52.4 & 50.1 & 42.8 & 40.5 & 1.2 & 0.27 \\
\hline Czech Rep. & 338.4 & 426.6 & 534.3 & 88.2 & 195.9 & 10.63 & 2.40 \\
\hline Denmark & 16.4 & 95.1 & 354.5 & 78.7 & 338.1 & 5.78 & 1.30 \\
\hline Estonia & 30.2 & 80.6 & 93.2 & 50.4 & 63 & 1.3 & 0.29 \\
\hline Finland & 122.2 & 409.6 & 412.7 & 287.4 & 290.5 & 5.56 & 1.25 \\
\hline France & 2679.2 & 3839.3 & 0.0 & 1160.1 & -2679.2 & 65.48 & 14.77 \\
\hline Germany & 879.7 & 0.0 & 3732.8 & -879.7 & 2853.1 & 82.43 & 18.59 \\
\hline Greece & 257.0 & 593.9 & 620.3 & 336.9 & 363.3 & 11.12 & 2.51 \\
\hline Hungary & 548.5 & 611.0 & 733.0 & 62.5 & 184.5 & 9.66 & 2.18 \\
\hline Ireland & 0.0 & 159.4 & 259.2 & 159.4 & 259.2 & 4.85 & 1.09 \\
\hline Italy & 1550.7 & 2685.4 & 646.4 & 1134.7 & -904.3 & 59.22 & 13.36 \\
\hline Latvia & 69.5 & 124.4 & 127.0 & 54.9 & 57.5 & 1.91 & 0.43 \\
\hline Lithuania & 103.1 & 196.9 & 209.8 & 93.8 & 106.7 & 2.86 & 0.64 \\
\hline Luxembourg & - & - & - & - & - & 0.62 & 0.14 \\
\hline Malta & 3.3 & 32.7 & 30.4 & 29.4 & 27.1 & 0.43 & 0.10 \\
\hline Netherlands & 59.2 & 135.8 & 943.1 & 76.6 & 883.9 & 17.13 & 3.86 \\
\hline Poland & 1267.9 & 1872.0 & 2268.7 & 604.1 & 1000.8 & 38.03 & 8.58 \\
\hline Portugal & 362.2 & 589.0 & 198.1 & 226.8 & -164.1 & 10.25 & 2.31 \\
\hline Romania & 924.6 & 1301.0 & 611.3 & 376.4 & -313.3 & 19.48 & 4.39 \\
\hline Slovak Rep. & 182.8 & 214.6 & 323.3 & 31.8 & 140.5 & 5.45 & 1.23 \\
\hline Slovenia & 21.8 & 71.3 & 102.7 & 49.5 & 80.9 & 2.08 & 0.47 \\
\hline Spain & 1425.0 & 2155.3 & 712.6 & 730.3 & -712.4 & 46.44 & 10.47 \\
\hline Sweden & 14.3 & 203.3 & 540.2 & 189 & 525.9 & 10.05 & 2.27 \\
\hline Total & 11443.2 & 16682.1 & 14617.6 & 5238.9 & 3174.4 & 443.42 & 100 \\
\hline
\end{tabular}

SOURCE: Own elaboration. 
goes in the other direction since the countries for which German (resp. French) yields the lowest sacrifice represent 20 (resp. 50) \% of the population. This last argument goes therefore in favour of French.

\subsection{German or French, but not English}

As argued above, it may well happen that English is not considered as a possible lingua franca after Brexit. This leads us to a choice between German and French only. Columns (5)-(6) of Table 2 show the change of sacrifices that each country would face moving from English as lingua franca $(E L F)$ to German as lingua franca $(G L F)$ or to French as lingua franca (FLF). They result from subtracting (2) from (3) for German and (2) from (4) for French. These numbers could be interpreted as the relative sacrifices associated to moving from $E L F$ to $G L F$ or $F L F$. Some numbers are negative and correspond to countries that would actually improve moving from $E L F$ to the new scenario.

For $G L F$, there are only two such countries (Germany and Austria), which is expected, since their official language is German. For $F L F$, in addition to France and Belgium where French is an official language, there are other countries (Italy, Portugal, Romania and Spain, all belonging to the romance linguistic branch) which improve their situation, since their languages are close to French, and linguistic distances are accounted for in equation $\left(^{*}\right)$. A first conclusion is therefore that more countries benefit moving from ELF to FLF than to $G L F .^{24}$

The majority of countries (18), nevertheless, do not benefit if they move from $E L F$ to any of the alternative options. As already mentioned, if English were chosen, the sacrifice would be lowest in 18 countries (dark shaded cells in that column).

But we can explore whether they sacrifice more from moving to one or the other. It turns out that, beyond the countries already mentioned (France, Belgium, Italy, Portugal, Romania and Spain) only two (Malta and Cyprus, which are both very small) sacrifice less by moving from $E L F$ to $F L F$. All the remaining countries (thus, many more) sacrifice less moving from $E L F$ to $G L F$. This is also so in terms of citizens as the combined population of France, Belgium, Italy, Portugal, Romania, Spain, Cyprus and Malta is, nowadays, around 16 million smaller than the combined population of the rest of the countries.

This indicates that there are arguments to support either German or French. We, nevertheless, believe that German has slightly stronger arguments. If, ultimately, the decision would come to a vote (by the European Council, or by other instances), we should explore the outcome beyond considering only the number of countries and populations independently. We get back to this in the next section.

${ }^{24}$ More citizens too, as the combined population of France, Belgium, Italy, Portugal, Romania and Spain is more than twice as large as the combined population of Germany and Austria. 
Our main results in this section can thus be summarized as follows:

(a) more countries (and a higher number of EU citizens) make a negative sacrifice (i.e., improve) moving from $E L F$ to $F L F$ than to $G L F$.

(b) more countries (and a higher number of EU citizens) face a lower sacrifice moving from $E L F$ to $G L F$ than to $F L F$.

\section{Voting on the lingua franca}

The discussion in Section 4 shows that there are arguments for (and against) each of the three candidate languages. We now move from a normative to a positive analysis, assuming that a vote, within post-Brexit EU, should be organized. ${ }^{25}$ This raises two immediate issues: Who should vote, and how should the votes be counted.

Depending on the issue under discussion, the Council of the EU takes its decisions by: ${ }^{26}$

1. Simple majority (15 member states vote in favour) $; 27$

2. Qualified majority (55\% of member states, representing at least $65 \%$ of the EU population, vote in favour);

3. Unanimous vote (all member states vote in favour).

Article 342 of the Lisbon Treaty implies that decisions on languages have to be unanimous, but, as we argue in Section 2, this will almost surely not work. The last paragraphs of Section 4 suggest that no language would achieve a qualified majority either. Assuming that there is no strategic voting and countries vote for the language yielding the lowest sacrifice, the plurality winner (counting a vote from each country) would be English. But the countries voting for English would not achieve the threshold of $65 \%$ of the EU population (they only achieve about half of that threshold). French would actually be the language getting closer to meet this threshold, but would still be far away. And, moreover, it would be far away from the number of countries threshold (55\% of member states), achieving only half of it.

In summary, only the first voting rule of the Council (simple majority) would guarantee the existence of a (language) winner, which would be English (although the countries voting for it would represent less than one third of the population in the post-Brexit EU), followed by French and German. Thus:

$$
\text { English } \gtrsim \text { French } \gtrsim \text { German. }
$$

\footnotetext{
${ }^{25}$ Fidrmuc et al. (2009) analyze a somewhat related voting problem.

${ }^{26} \mathrm{https} / / / \mathrm{www} . c o n s i l i u m . e u r o p a . e u / e n /$ council-eu/voting-system/.

${ }^{27}$ These are, obviously, not post-Brexit rules. We can only assume that they would be adjusted naturally after Brexit (for instance, the first item would mention 14, instead of 15).
} 
In terms of population, plurality voting would yield the ranking:

$$
\text { French } \gtrsim \text { English } \gtrsim \text { German. }
$$

A so-called Condorcet voting (i.e., successive pairwise voting), would yield the same ranking in the two possible scenarios: one in which we count one vote per citizen, another in which we count one vote per country:

$$
\text { English } \gtrsim \text { German } \gtrsim \text { French }
$$

German never wins the race in the three-language contest. Things would be different without English. It would still be impossible to reach a winner via unanimity or qualified majority, but German would get close to be the winner in that case, since 18 countries representing almost $52 \%$ of the population would prefer it to French.

Two caveats should be made about the previous analysis, that refer to Belgium and Luxembourg. Our analysis assumed that each country had a unique official language, which is not the case of Belgium. To deal with this issue, we assumed that its official language was set at a weighted sum of the distances from Flemish and French to the lingua franca (with weights 0.6 and 0.4 , respectively, representing the shares of Flemish and French speaking populations) ${ }^{28}$ This allowed us to obtain a claim and a sacrifice for Belgium, as we did with the other 25 countries in the list, from which we inferred its voting behaviour. But we could estimate its voting behaviour assuming instead that $40 \%$ of its population (French native speakers) would vote for French no matter what, whereas the other $60 \%$ would either vote for German (which is closer to Flemish according to the lexicographic distance), or would vote as the Netherlands do.$^{29}$ None of these options would alter the previous results: English would be the plurality winner in terms of number of countries, whereas French would be the plurality winner in terms of population. German would win the two-language contest to French, once English is dismissed.

As for Luxembourg, we excluded it from our analysis because its language, (Letzebuergesch), is, for the time being, not an EU official language. Thus, we neither computed claims nor sacrifices for it. But we should certainly let its citizens vote. We could actually do what we did for Belgium: $40 \%$ of its population would vote for German, whereas the other $60 \%$ would vote for French. ${ }^{30}$ We could also construct an artificial claim assuming that its official language is at a weighted sum of the distances from German and French to the lingua franca (with weights 0.4

\footnotetext{
${ }^{28}$ We ignore German, which is spoken by a small number of Belgian citizens in the Eastern part of the country.

${ }^{29}$ In terms of population, the two groups would represent, respectively, $1 \%$ and $1.61 \%$ of the EU's population.

${ }^{30}$ In terms of population, the two groups would represent, respectively, $0.2 \%$ and $0.3 \%$ of the EU's population.
} 
and 0.6, respectively). Again, none of these options would alter the previous results, given the very small populations.

\section{Conclusions}

We assume that the European Commission would be able and willing to provide a new budget to acquire a common language. Without Brexit, it seems that the decision to choose English would have been obvious. This is less so in the postBrexit scenario, where we consider three possible candidates: German and French, as well as English, even if it may no longer be an official language. ${ }^{31}$ Our analysis shows that any choice is possible. It seems that decisions in the EU are never easy and politicians should not be blamed! The Commission may also always consider as reasonable to have the whole population voting, with the exception of countries where English, German or French are native languages.

\section{References}

Barancicová, J., \& Zerzová, J. (2015). English as a lingua franca used at international meetings. Journal of Language and Cultural Education, 3, 30-51.

De Witte, B. (2019). Private communication.

Dyen, I., Kruskal, J., \& Black, P. (1992). An Indo-European classification: A lexicostatistical experiment. Transactions of the American Philosophical Society, 82.

European Commission (2017). Erasmus +Programme Guide, Version 2.

http://ec.europa.eu/programmes/erasmus-plus

Fidrmuc, J., Ginsburgh, V., \& Weber, S. (2007). Ever closer Union or Babylonian discord? The official-language problem in the European Union. CEPR Discussion Paper 6367.

Fidrmuc, J., Ginsburgh, V., \& Weber, S. (2009). Voting on the choice of core languages in the European Union. European Journal of Political Economy, 25, 56-62.

Ginsburgh, V., \& Moreno-Ternero J. D. (2018). Compensation schemes for learning a lingua franca in the European Union. The World Economy, 41, 1775-1789.

Ginsburgh, V., Moreno-Ternero J. D., \& Weber, S. (2017). Ranking languages in the European Union: Before and after Brexit. European Economic Review, 93, 139-151.

Graddol, D. (2006). English Next: Why Global English May Mean the End of English as a Foreign Language. London: British Council.

Grin, F. (2005). L'enseignement des langues étrangères comme politique publique. Paris: Haut Conseil de l'Evaluation de l'Ecole.

Mair, C. (2019). Brexitiness: The ebbs and flows of British eurosceptic rhetoric since 1945. Open Library of Humanities, 5, 1-26.

Melitz, J. (2016). English as a global language. Chapter 20. In V. Ginsburgh, S. Weber (Eds.), The Palgrave Handbook of Economics and Language. Palgrave. Macmillan.

${ }^{31}$ Note that English is already considered as a lingua franca at international meetings (Barancicová and Zerzová, 2015). 
Modiano, M. (2017). English in a post-Brexit European Union. World Englishes 36, 313-327. O'Neill, B. (1982). A problem of rights arbitration from the Talmud. Mathematical Social Sciences, 2(4), 345-371.

Special Eurobarometer 243 (2006). Europeans and their Languages.

Special Eurobarometer 386 (2012). Europeans and their Languages.

Thomson, W. (2003). Axiomatic and game-theoretic analysis of bankruptcy and taxation problems: A survey. Mathematical Social Sciences, 45(3), 249-297.

Thomson, W. (2015). Axiomatic and game-theoretic analysis of bankruptcy and taxation problems: An update. Mathematical Social Sciences, 74, 41-59

Thomson, W. (2019). How to Divide When There Isn't Enough: From Aristotle, the Talmud, and Maimonides to the Axiomatics of Resource Allocation. Cambridge: Cambridge University Press. 